[Research Note]

\title{
Nitric Oxide Synthases and Heart Failure - Lessons from Genetically Manipulated Mice
}

\author{
Kiyoko Shibata ${ }^{1}$, Hiroaki Shimokawa ${ }^{2}$, Nobuyuki Yanagihara ${ }^{3}$, Yutaka Otsuji ${ }^{1}$ and Masato Tsutsui, ${ }^{4}$ * \\ ${ }^{1}$ Department of Second Internal Medicine, School of Medicine, University of Occupational and Environmental Health, \\ Japan. Yahatanishi-ku, Kitakyushu 807-8555, Japan \\ ${ }^{2}$ Department of Cardiovascular Medicine, Tohoku University Graduate School of Medicine, Japan. Aoba-ku, Sendai \\ 980-8575, Japan \\ ${ }^{3}$ Department of Pharmacology, School of Medicine University of Occupational and Environmental Health, Japan. \\ Yahatanishi-ku, Kitakyushu 807-8555, Japan \\ ${ }^{4}$ Department of Pharmacology, Graduate School of Medicine, University of the Ryukyus, Japan. Nishihara, Okinawa \\ 903-0215, Japan
}

\begin{abstract}
Nitric oxide (NO) is synthesized by three distinct NO synthase (NOS) isoforms (neuronal, inducible, and endothelial NOS), all of which are expressed in the human heart. The roles of NOSs in the pathogenesis of heart failure have been described in pharmacological studies with NOS inhibitors. Recently, genetically engineered animals have been used. We have generated mice in which all 3 NOS isoforms are completely disrupted (triple $\mathrm{n} / \mathrm{i} /$ $\mathrm{eNOS}^{-/-}$mice). Morphological, echocardiographic, and hemodynamic analysis were performed in wild-type, singly $\mathrm{nNOS}^{-{ }^{--}}, \mathrm{iNOS}^{-\nu_{-}}, \mathrm{eNOS}^{-\nu^{-}}$, and triple $\mathrm{n} / \mathrm{i} / \mathrm{eNOS}^{-\nu^{-}}$mice. Importantly, significant left ventricular (LV) hypertrophy and diastolic dysfunction was noted only in $\mathrm{n} / \mathrm{i} / \mathrm{eNOS}^{-/}$mice, and those pathology was similar to diastolic heart failure in humans. Finally, treatment with an angiotensin II type 1 (AT1) receptor blocker, significantly prevented those abnormalities. These results provide the evidence that AT1 receptor pathway plays a center role in the pathogenesis of cardiac disorders in the $\mathrm{n} / \mathrm{i} / \mathrm{eNOS}^{-/-}$mice. Our studies with triple $\mathrm{n} / \mathrm{i} / \mathrm{eNOS}^{-/-}$mice provide pivotal insights into an understanding of the pathophysiology of NOSs in human heart failure.
\end{abstract}

Keywords : nitric oxide synthase, heart failure, left ventricular hypertrophy, mice.

(Received July 27, 2012, accepted April 9, 2013)

\section{Introduction}

Nitric oxide (NO) possesses multiple biological actions that contribute to the maintenance of cardiovascular homeostasis [1-6]. NO is formed from its precursor L-arginine by a family of NO synthases (NOSs) with stoichiometric production of L-citrulline. The
NOS system consists of three different NOS isoforms, encoded by three distinct NOS genes, including neuronal (nNOS; also known as NOS-1), inducible (iNOS; also known as NOS-2) and endothelial NOS (eNOS; also known as NOS-3).

It was initially indicated that nNOS and eNOS are constitutively expressed mainly in the nervous system

*Corresponding author: Masato Tsutsui, MD, PhD, Department of Pharmacology, Graduate School of Medicine, University of the Ryukyus, 207 Uehara, Nishihara, Okinawa 903-0215, Japan. Phone: +81-98-895-1133, Fax: +81-98-895-1411, E-mail: tsutsui@med.u-ryukyu.ac.jp 
and the vascular endothelium, respectively, synthesizing a small amount of NO in a calcium-dependent manner both under basal conditions and upon stimulation, and that iNOS is induced only when stimulated by microbial endotoxins or certain proinflammatory cytokines, producing a greater amount of $\mathrm{NO}$ in a calciumindependent manner [1-6]. However, recent studies have revealed that both $\mathrm{nNOS}$ and eNOS are subject to expressional regulation [7-11], and that iNOS is constitutively expressed even under physiological conditions $[12,13]$. In addition, it has become apparent that in addition to eNOS and iNOS, nNOS also plays important roles in the cardiovascular system.

Genetically engineered animals are a powerful experimental tool to study the function of target genes in vivo. All types of NOS gene-knockout (KO) animals, including singly, doubly, and triply NOS-KO mice, have been generated (Table 1) [14-25]. Furthermore, various types of NOS gene-transgenic (TG) animals, including conditional and non-conditional TG mice with endothelium-specific or cardiomyocyte-specific overexpression of each NOS isoform, have also been established (Table 2) [26-35]. By using those genetically modified mice, the roles of NOSs in the pathogenesis of heart failure have been extensively studied, and the findings provide pivotal insights into the significance of NOSs in human heart failure. In this review, we summarize the current knowledge of NOSs and heart failure on the basis of research outcomes obtained from the NOS gene-modified mice.

Table 1. Mice lacking the NOS gene that have thus far been established

\begin{tabular}{|c|c|c|c|}
\hline KO Mice & Sites of gene deletion & Authors & References \\
\hline \multirow[t]{3}{*}{ nNOS-KO } & exon $2(\# 1)$ & Huang PL, et al & (1993): Cell 75: 1273-1286 \\
\hline & exon 6 & Gyurko R, et al & (2002): Endocrinology 143: 2767-2774 \\
\hline & exon 6 & Packer MA, et al & (2003): PNAS 100: 9566-9571 \\
\hline \multirow[t]{3}{*}{ iNOS-KO } & proximal 585 bases of promoter plus exons 1-4 (\#2) & MacMicking JD, et al & (1995): Cell 81: 641-650 \\
\hline & near exons $1-5$ & Wei X, et al & (1995): Nature 375: 408-411 \\
\hline & exons 12 and 13 and a part of exon $11(\# 3)$ & Laubach VE, et al & (1995): PNAS 92: 10688-10692 \\
\hline \multirow[t]{3}{*}{ eNOS-KO } & exons 24-26 (\#4) & Huang PL, et al & (1995): Nature 377: 239-242 \\
\hline & exon 12(\#5) & Shesely EG, et al & (1996): PNAS 93: 13176-13181 \\
\hline & exons 24 and 25 & Godecke A, et al & (1998): Circ Res 82: 186-194 \\
\hline \multirow[t]{2}{*}{$\mathrm{n} / \mathrm{iNOS}-\mathrm{KO}$} & $\# 1$ and \#3 & Tranguch S, et al & (2003): Mol Reprod Dev 65: 175-179 \\
\hline & $\# 1$ and $\# 2$ & Morishita T, et al & (2005): PNAS 102: 10616-10621 \\
\hline \multirow[t]{3}{*}{ n/eNOS-KO } & $\# 1$ and $\# 4$ & Son $\mathrm{H}$, et al & (1996): Cell 87: 1015-1023 \\
\hline & $\# 1$ and \#5 & Tranguch S, et al & (2003): Mol Reprod Dev 65: 175-179 \\
\hline & $\# 1$ and \#4 & Morishita $\mathrm{T}$, et al & (2005): PNAS 102: 10616-10621 \\
\hline \multirow[t]{2}{*}{ i/eNOS-KO } & $\# 3$ and $\# 5$ & Tranguch S, et al & (2003): Mol Reprod Dev 65: 175-179 \\
\hline & $\# 2$ and \#4 & Morishita $\mathrm{T}$, et al & (2005): PNAS 102: 10616-10621 \\
\hline $\mathrm{n} / \mathrm{i} / \mathrm{eNOS}-\mathrm{KO}$ & $\# 1, \# 2$ and $\# 4$ & Morishita T, et al & (2005): PNAS 102: 10616-10621 \\
\hline
\end{tabular}


Table 2. Mice overexpressing the NOS gene that have thus far been established

\begin{tabular}{lllll}
\hline TG Mice & Overexpression site & Promoter used & Authors & References \\
\hline nNOS-TG & myocardium (conditional) & $\alpha-$ MHC & Burkard N, et al & (2007): Circ Res 100: e32-e44 \\
& myocardium (conditional) & $\alpha-$ MHC & Loyer X, et al & (2008): Circulation 117: 3187-3198 \\
& brain & CaMKII $\alpha$ & Packer MA, et al & (2005): Cell Mol Biol 51: 269-277 \\
iNOS-TG & myocardium (conditional) & $\alpha-$-MHC & & \\
& myocardium & $\alpha-M H C$ & Mungrue I, et al & (2002): J Clin Invest 109: 735-743 \\
& pancreatic $\beta$ cell & insulin & Heger J, et al & (2002): Circ Res 90: 93-99 \\
& & & Takamura T, et al & (1998): J Biol Chem 273: 2493-2496 \\
eNOS-TG & endothelium & preproendothelin-1 & Ohashi Y, et al & (1998): J Clin Invest 102: 2061-2071 \\
& endothelium & eNOS & van Haperen R, et al & (2002): J Biol Chem 277: 48803-48807 \\
& myocardium & $\alpha-M H C$ & Brunner F, et al & (2001): Circulation 104: 3097-3102 \\
& myocardium & $\alpha-M H C$ & Janssens S, et al & (2004): Circ Res 94: 1256-1262
\end{tabular}

CaMKII: calcium-calmodulin multifunctional kinase II, MHC: myosin heavy chain, TG: transgenic

\section{Role of eNOS in Heart Failure}

Congestive heart failure can be induced by permanent ligation of the coronary artery (i.e. myocardial infarction) and by transverse aortic constriction (i.e. pressure overload), respectively, in animals. Cardiomyocyte-restricted eNOS-TG mice with a 30-fold increase in cardiac NOS activity showed protection against detrimental left ventricular (LV) remodeling after coronary artery ligation, exhibiting improved LV systolic and diastolic function and attenuation of LV hypertrophy [29]. Endothelium-specific eNOS-TG mice with a 12-fold increase in vascular NOS activity also exhibited improvement of survival, LV dysfunction, and pulmonary edema following coronary ligation without affecting LV remodeling [36]. Consistent with these findings, eNOS-KO mice with heart failure due to myocardial infarction [37] or to pressure overload [38] displayed exacerbation of survival, LV remodeling, and LV dysfunction. It has also been reported that the presence of eNOS mediates the beneficial cardiovascular protective effects of statins [39], angiotensinconverting enzyme inhibitors [40], angiotensin II type 1 receptor blockers [40], and corticosteroids [41] in ex- perimental heart failure. Thus, it is evident that eNOS plays a protective role in heart failure $[42,43]$.

\section{Role of nNOS in Heart Failure}

Conditionallytargetedcardiomyocyte-specificnNOSTG mice with a 5-fold increase in cardiac NOS activity indicated delayed transition toward heart failure in response to pressure overload [30]. In agreement with the evidence, two strains of nNOS-KO mice with myocardial infarction-induced heart failure similarly showed exacerbation of survival, pathological LV remodeling, or LV dysfunction after coronary artery ligation, although the findings were not totally identical in the two studies $[44,45]$. It is thus possible that in addition to eNOS, nNOS also plays a protective role in heart failure [46].

\section{Role of iNOS in Heart Failure}

Increased iNOS expression is noted in cardiomyocytes in septic shock, myocarditis, ischemia, and dilated cardiomyopathy, and has been implicated in the development of heart failure. However, cardiomyo- 
cyte-specific iNOS overexpression per se (in two different strains with either a 10-fold [31] or 40-fold increase [28] in cardiac NOS activity) did not result in heart failure, suggesting that increased iNOS expression is not the triggering factor of heart failure. On the other hand, iNOS-KO mice with heart failure induced by myocardial infarction [47-49] and by pressure overload [50] showed improved survival, lessened LV remodeling and dysfunction, and decreased myocardial apoptosis. Furthermore, iNOS-KO mice with heart failure induced by cardio-specific overexpression of tumor necrosis factor- $\alpha$ exhibited improved $\beta$-adrenergic inotropic responsiveness. It is thus possible that in contrast to eNOS and nNOS, iNOS exerts an opposite, unfavorable role in heart failure status. The underlying mechanisms for the contrasting roles among NOS isoforms in heart failure are unclear, but may relate to differences in spatial localization, expressional regulation, NO-generating capacity, or peroxynitrite generation $[43,51,52]$.

\section{Role of the Entire NOS System in Heart Failure}

The roles of the NOS system in vivo have been investigated in pharmacological studies. As pharmacological tools used to inhibit NO synthesis, L-arginine analogues have been widely used. However, the Larginine analogues possess multiple non-specific actions $[53,54]$. Indeed, we clarified the NO-independent vascular actions of L-arginine analogues (e.g. a synthetic analogue, $N^{\omega}$-nitro-L-arginine methyl ester, and an endogenous analogue, asymmetric dimethylarginine). Although long-term treatment with L-arginine analogues had long been believed without doubt to simply inhibit vascular NO synthesis and cause arteriosclerotic vascular lesion formation, we found that the long-term vascular effects of L-arginine analogues are not solely mediated by the simple inhibition of vascular NO synthesis [53, 54]. Activation of the tissue renin-angiotensin system and increased oxidative stress, independent of endogenous NO inhibition, are involved in the long-term vascular effects of those analogues $[53,54]$. These findings questioned the pre- vious theory regarding the effects of L-arginine analogues, and warranted re-evaluation of previous studies using those analogues $[53,54]$. Thus, due to their non-specificity, the authentic roles of the NOS system in our body still remain to be fully elucidated.

To address this issue, we have generated mice in which all three NOS isoforms are completely disrupted (triply $\mathrm{n} / \mathrm{i} / \mathrm{eNOS}^{-/-}$mice) $[20,55]$. The $\mathrm{n} / \mathrm{i} / \mathrm{eNOS}^{-/}$ mice are unexpectedly viable and appear normal, but their survival and fertility rates are markedly reduced as compared with wild-type (WT) mice. The $n / \mathrm{i} /$ $\mathrm{eNOS}^{-/-}$mice spontaneously develop cardiovascular diseases, including hypertension, dyslipidemia, and arteriosclerosis [56, 57]. It, however, remains to be determined whether or not the NOS system plays a role in maintaining cardiac architecture and function. We thus addressed this point in our triply mutant mice.

Morphological, echocardiographic, and hemodynamic analyses were performed in wild-type (WT), singly $\mathrm{nNOS}^{-/-}, \mathrm{iNOS}^{-/-}, \mathrm{eNOS}^{-/-}$, and triply $\mathrm{n} / \mathrm{i} /$ $\mathrm{eNOS}^{-/-}$mice. At 5 months of age, but not at 2 months of age, significant LV hypertrophy was noted in $\mathrm{n} / \mathrm{i}$ / $\mathrm{eNOS}^{-/-}$mice and to a lesser extent in $\mathrm{eNOS}^{-/-}$mice, but not in $\mathrm{nNOS}^{-\nu_{-}}$or $\mathrm{iNOS}^{-\nu_{-}}$mice, compared with WT mice (Fig. 1). Importantly, significant LV diastolic dysfunction (as evaluated by echocardiographic E/A wave ratio and hemodynamic $-\mathrm{dP} / \mathrm{dt}$ and $\mathrm{Tau}$ ), with preserved LV systolic function (as assessed by echocardiographic fractional shortening and hemodynamic $+\mathrm{dP} / \mathrm{dt}$ ) (Fig. 2), was noted only in $\mathrm{n} / \mathrm{i} / \mathrm{eNOS}^{-/-}$mice, and this was associated with enhanced LV end-diastolic pressure (LVEDP) and increased lung wet weight (Figure 3), all of which are characteristics consistent with diastolic heart failure in humans. Finally, longterm oral treatment with an angiotensin II type $1\left(\mathrm{AT}_{1}\right)$ receptor blocker olmesartan significantly prevented all these abnormalities of $\mathrm{n} / \mathrm{i} / \mathrm{eNOS}^{-/-}$mice. These results provide the first direct evidence that the complete disruption of all NOS genes results in LV hypertrophy and diastolic dysfunction in mice in vivo through the $\mathrm{AT}_{1}$ receptor pathway, demonstrating a pivotal role of the NOS system in preventing diastolic heart failure [58]. 
A

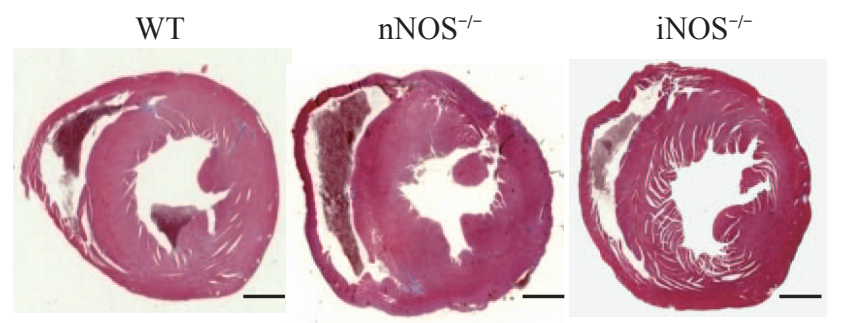

$\mathrm{eNOS}^{-1-}$

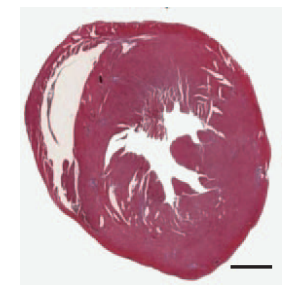

B

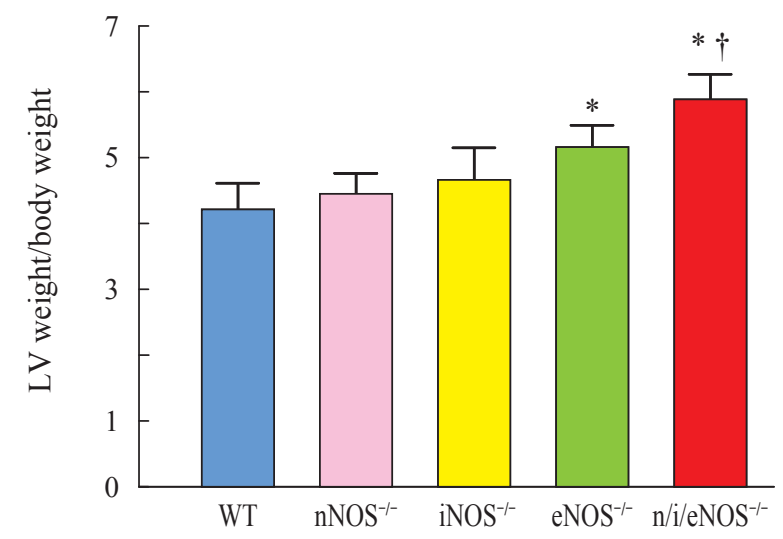

D

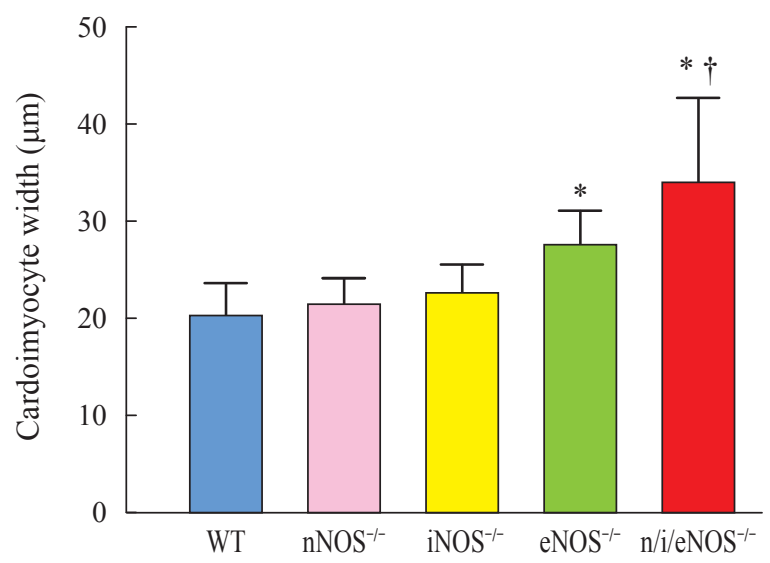

Fig. 1. Left ventricular (LV) and cardiac myocyte hypertrophy in 5-month-old n/i/eNOS ${ }^{-/}$and $\mathrm{eNOS}^{-/-}$mice. A: Centripetal concentric LV hypertrophy $(\mathrm{LVH})$ in $\mathrm{n} / \mathrm{i} / \mathrm{eNOS}^{-/-}$and $\mathrm{eNOS}^{-/-}$mice. Scale bars, $1 \mathrm{~mm}$. B: The ratio of LV weight/body weight ( $\mathrm{n}=5-7)$. C, D: Cardiac myocyte hypertrophy in $\mathrm{n} / \mathrm{i} / \mathrm{eNOS}^{-{ }^{--}}$and $\mathrm{eNOS}^{-/-}$mice $(\mathrm{n}=5-7)$. Arrows in panel $\mathrm{C}$ indicate the border of each cardiac myocyte. Scale bars in panel C, $0.02 \mathrm{~mm} . * *: P<0.05 \mathrm{vs}$. WT, $\uparrow: P<0.05 \mathrm{vs}$. eNOS ${ }^{-{ }^{-}}$. (Reproduced from ref. Shibata et al. (2010) with permission of the Circulation Journal Press)

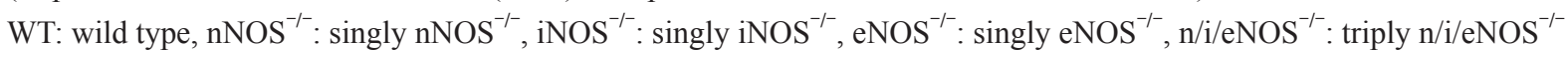


A
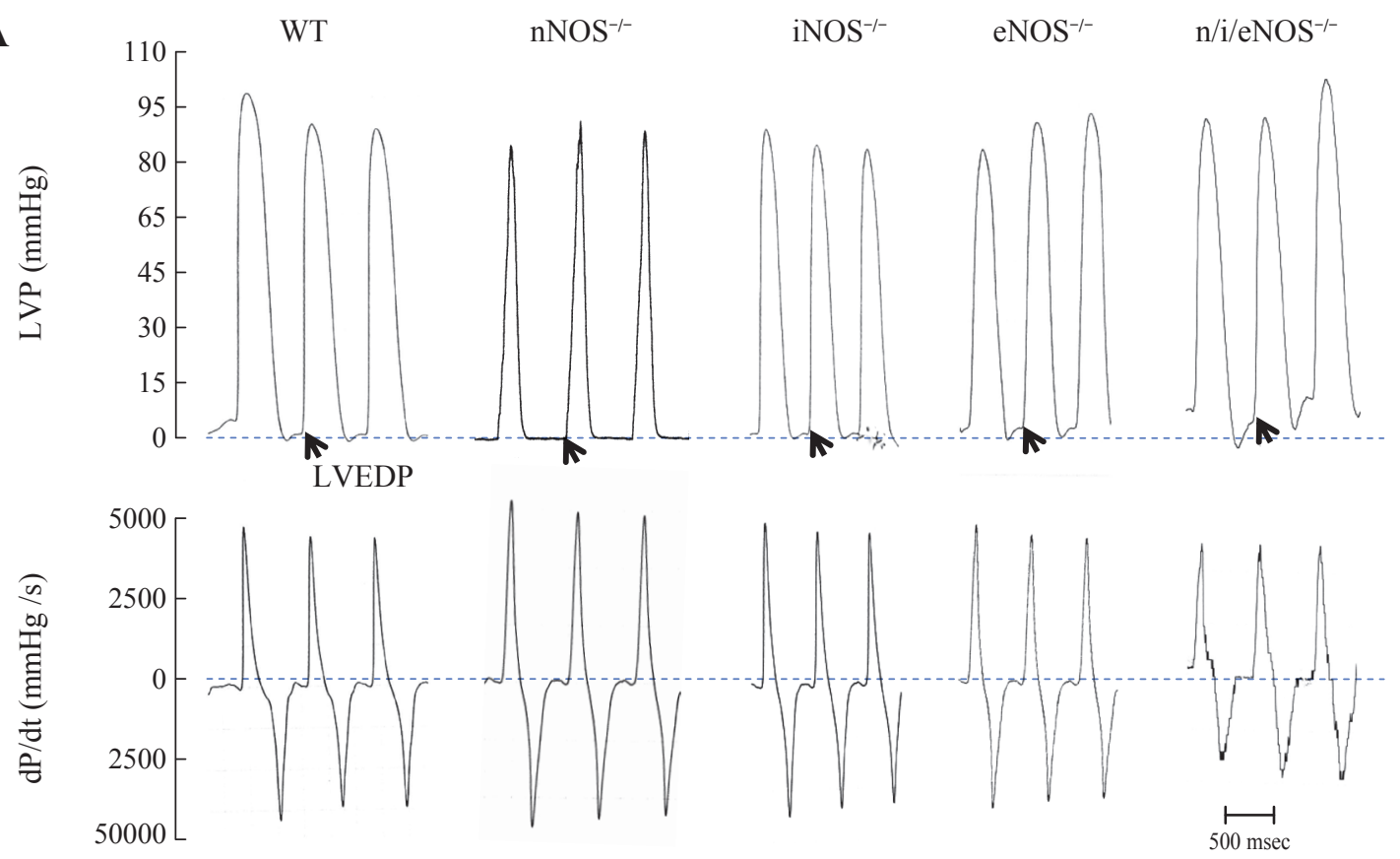

B

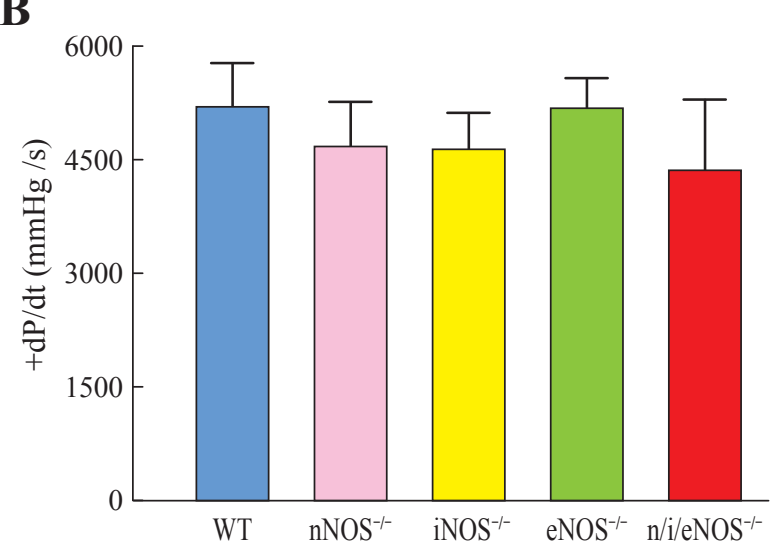

D

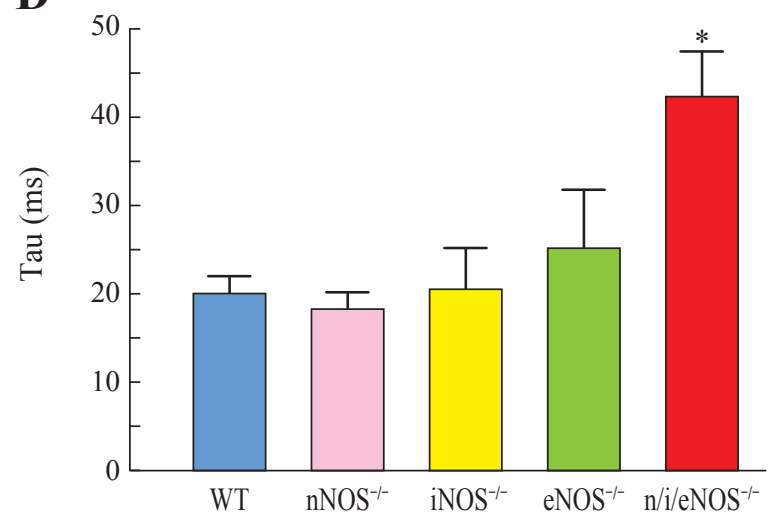

C $\quad 5000$ -

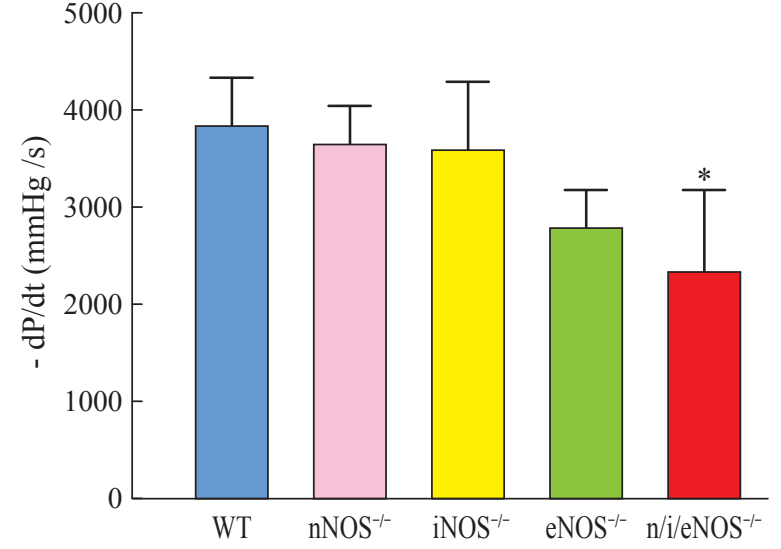

$\mathbf{E}$

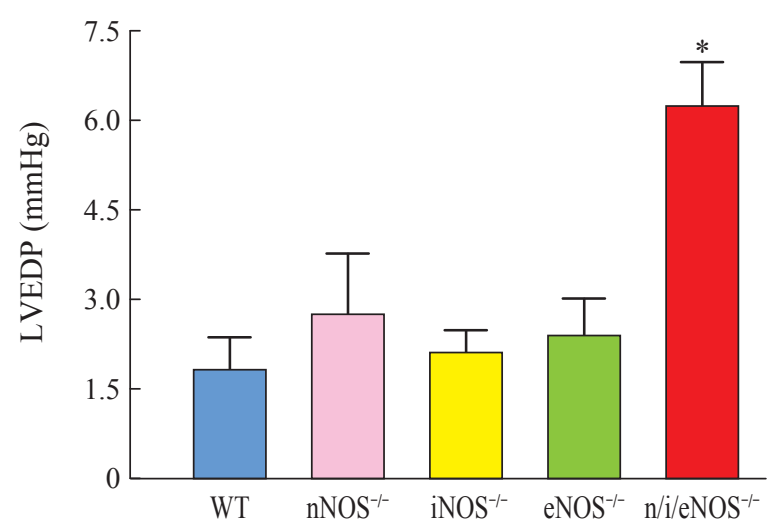

Fig. 2. Diastolic dysfunction in $\mathbf{n} / \mathbf{i} / \mathrm{eNOS}^{-/-}$mice assessed by cardiac catheterization. A: Representative traces of $\mathrm{LV}$ pressure (LVP) and dP/dt. Arrows indicate LV end-diastolic pressure (LVEDP), B-E: Hemodynamic parameters ( $\mathrm{n}=5-6)$, $+\mathrm{dP} / \mathrm{dt}$ : peak positive $\mathrm{dP} / \mathrm{dt}$, $-\mathrm{dP} / \mathrm{dt}$ : peak negative $\mathrm{dP} / \mathrm{dt},{ }^{*}: P<0.05$ vs. WT. (Reproduced from ref. Shibata et al. (2010) with permission of the Circulation Journal Press) 
A

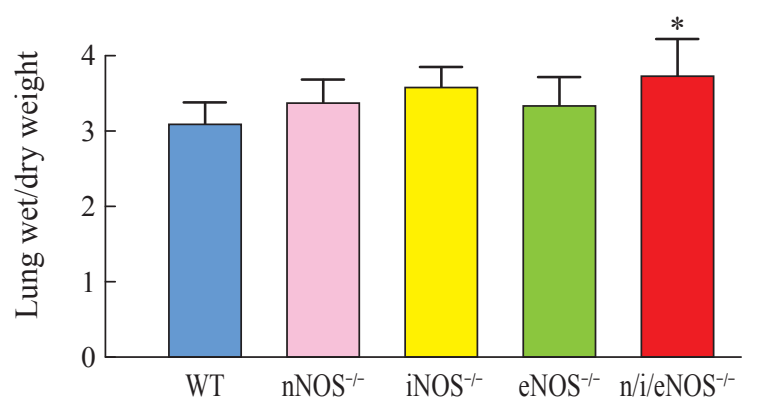

C

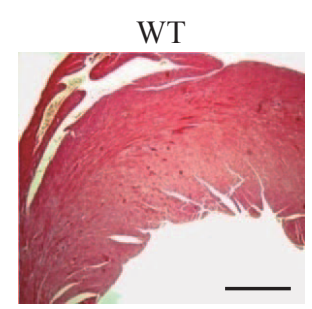

$\mathrm{nNOS}^{-/-}$

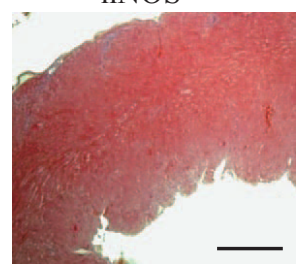

$\mathrm{iNOS}^{-/-}$
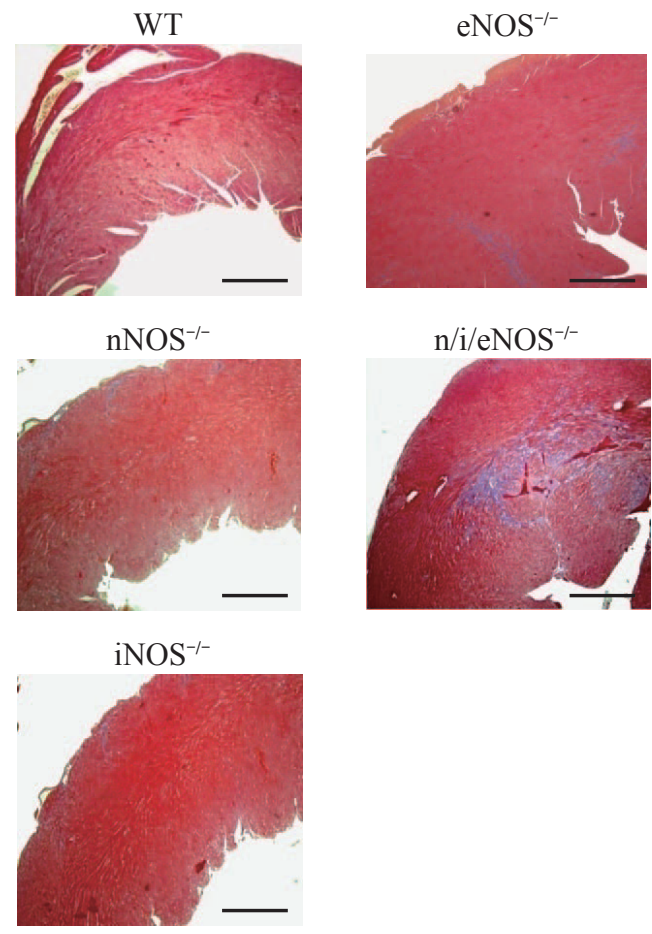

$\mathrm{n} / \mathrm{i} / \mathrm{eNOS}^{-/-}$

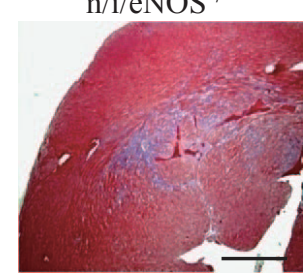

B

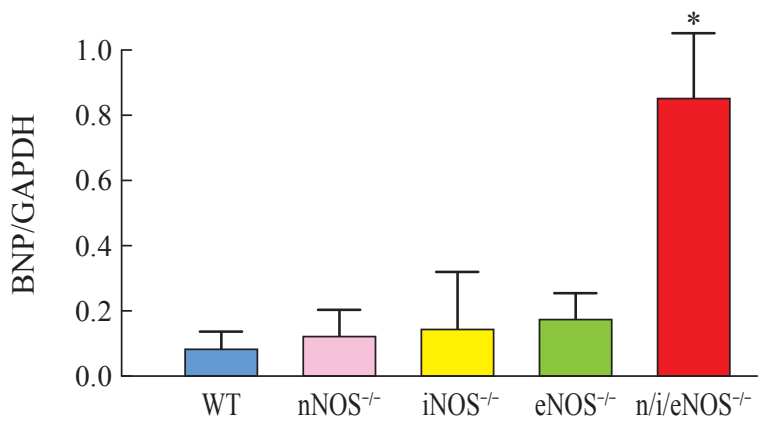

D

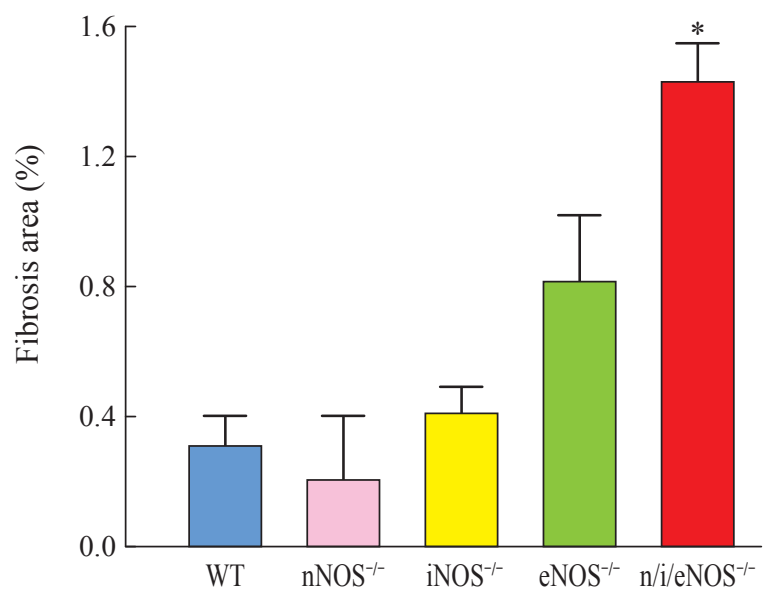

\section{$\mathbf{E}$}




\section{Murine Model of Spontaneous Diastolic Heart Failure}

Heart failure is a leading cause of morbidity and mortality in industrialized countries [59,60]. There is growing recognition that not only systolic heart failure but also diastolic heart failure with normal systolic function is common and causes significant morbidity and mortality. Indeed, recent studies have revealed that as many as $30-50 \%$ of patients with congestive heart failure have diastolic heart failure, and that the morbidity and mortality rates for diastolic heart failure are nearly identical to those for systolic heart failure in aged patients [61]. Based on these new lines of evidence, diastolic heart failure has currently attracted considerable attention.

Thus far, 4 genetically engineered mouse models that spontaneously develop diastolic dysfunction in the absence of systolic dysfunction have been reported: 1) mice lacking the $\alpha_{1}$ subunit of soluble guanylate cyclase $[62], 2)$ mice deficient in the peptide hormone relaxin [61, 63], 3) mice overexpressing cardiac ACE [64], and 4) mice bearing R58Q mutation of the ventricular myosin regulatory light chain [65]. However, no evidence of heart failure has been present in the former two mice, and indexes of heart failure (e.g. LVEDP) have not been studied in the latter two mice. On the other hand, we demonstrated that the $\mathrm{n} / \mathrm{i} / \mathrm{eNOS}^{-/}$mice showed higher LVEDP and increased lung wet weight in addition to diastolic dysfunction. Thus, our triply mutant mice may be the first genetically engineered murine model of spontaneous diastolic heart failure [58]. In human patients with diastolic heart failure, the expression level of three NOS isoforms or the level of NO production has not been reported. Thus, the significance of the $\mathrm{n} / \mathrm{i} /$ $\mathrm{eNOS}^{--}$mice as a model of human diastolic heart failure remains to be clarified in future studies.

$\mathrm{NO}$ attenuates cardiac myocyte hypertrophy and cardiac fibrosis in response to norepinephrine stimulation in cultured rat LV cells [66], and NO augments LV diastolic distensibility and myocardial relaxation in isolated mammalian beating hearts and in humans [67]. Furthermore, an increase in cardiac eNOS expression induced by pharmacological treatment with the eNOS enhancer AVE3085 has been shown to ameliorate diastolic heart failure in Dahl salt-sensitive rats. These results are in agreement with our evidence that loss of NO leads to cardiac myocyte hypertrophy, cardiac fibrosis, and diastolic dysfunction.

\section{Concluding Remarks}

The mouse is the most ideal genetically modifiable mammalian presently available [51]. Studies with mice that are deficient in or overexpressing NOSs provide pivotal insights into the cardiac pathophysiology of NOSs at the molecular level. These studies have demonstrated that, in the pathogenesis of heart failure, eNOS and nNOS exert cardiac protective roles, that iNOS exerts unfavorable roles, and that the NOS system in its entirety exerts salutary roles. The observations with the genetically modified animals have greatly advanced our understanding of the roles of NOSs in the pathogenesis of human heart failure. Further studies are certainly needed to clarify whether these outcomes can be translated to human patients with heart failure.

\section{Conflict of Interest}

None declared.

\section{References}

1. Bredt DS \& Snyder SH (1994): Nitric oxide: a physiological messenger molecule. Annu Rev Biochem 63: 175-195

2. Furchgott RF (1984): The role of endothelium in the responses of vascular smooth muscle to drugs. Annu Rev Pharmacol Toxicol 24: 175-197

3. Ignarro LJ (1990): Biosynthesis and metabolism of endothelium-derived nitric oxide. Annu Rev Pharmacol Toxicol 30: 535-560

4. Moncada S, Palmer RMJ \& Higgs EA (1991): Nitric oxide: physiology, pathophysiology, and pharmacology. Pharmacol Rev 43: 109-142

5. Murad F (1997): What are the molecular mechanisms for the antiproliferative effects of nitric oxide and cGMP in vascular smooth muscle? Circulation 95: $1101-1103$

6. Shimokawa H (1999): Primary endothelial dysfunction: atherosclerosis. J Mol Cell Cardiol 31: 23-37

7. Dudzinski DM, Igarashi J, Greif D \& Michel T (2006): 
The regulation and pharmacology of endothelial nitric oxide synthase. Annu Rev Pharmacol Toxicol 46: 235-276

8. Forstermann U, Boissel JP \& Kleinert H (1998): Expressional control of the 'constitutive' isoforms of nitric oxide synthase (NOS I and NOS III). FASEB J 12: 773-790

9. Nakata S, Tsutsui M, Shimokawa H et al (2005): Vascular neuronal NO synthase is selectively upregulated by platelet-derived growth factor. Arterioscler Thromb Vasc Biol 25: 2502-2508

10. Nakata S, Tsutsui M, Shimokawa H et al (2007): Statin treatment upregulates vascular neuronal nitric oxide synthase through Akt/NF-kappaB pathway. Arterioscler Thromb Vasc Biol 27: 92-98

11. Tsutsui M (2004): Neuronal nitric oxide synthase as a novel anti-atherogenic factor. J Atheroscler Thromb 11: $41-48$

12. Buchwalow IB, Podzuweit T, Bocker W, Samoilova VE, Thomas S, Wellner M, Baba HA, Robenek H, Schnekenburger J \& Lerch MM (2002): Vascular smooth muscle and nitric oxide synthase. FASEB J 16: 500-508

13. Park CS, Park R \& Krishna G (1996): Constitutive expression and structural diversity of inducible isoform of nitric oxide synthase in human tissues. Life Sci 59: 219-225

14. Godecke A, Decking UK, Ding Z, Hirchenhain J, Bidmon HJ, Godecke S \& Schrader J (1998): Coronary hemodynamics in endothelial NO synthase knockout mice. Circ Res 82: 186-94

15. Gyurko R, Leupen S \& Huang PL (2002): Deletion of exon 6 of the neuronal nitric oxide synthase gene in mice results in hypogonadism and infertility. Endocrinology 143: 2767-2774

16. Huang PL, Dawson TM, Bredt DS, Snyder SH \& Fishman MC (1993): Targeted disruption of the neuronal nitric oxide synthase gene. Cell 75: 1273-1286

17. Huang PL, Huang Z, Mashimo H, Bloch KD, Moskowitz MA, Bevan JA \& Fishman MC (1995): Hypertension in mice lacking the gene for endothelial nitric oxide synthase. Nature 377: 239-242

18. Laubach VE, Shesely EG, Smithies O \& Sherman PA (1995): Mice lacking inducible nitric oxide synthase are not resistant to lipopolysaccharide-induced death. Proc Natl Acad Sci U S A 92: 10688-10692

19. MacMicking JD, Nathan C, Hom G et al (1995): Altered responses to bacterial infection and endotoxic shock in mice lacking inducible nitric oxide synthase. Cell 81: 641-650

20. Morishita T, Tsutsui M, Shimokawa H et al (2005): Nephrogenic diabetes insipidus in mice lacking all nitric oxide synthase isoforms. Proc Natl Acad Sci U S A 102: 10616-10621

21. Packer MA, Stasiv Y, Benraiss A, Chmielnicki E, Grinberg A, Westphal H, Goldman SA \& Enikolopov G (2003): Nitric oxide negatively regulates mammalian adult neurogenesis. Proc Natl Acad Sci U S A 100: 9566-9571

22. Shesely EG, Maeda N, Kim HS, Desai KM, Krege JH, Laubach VE, Sherman PA, Sessa WC \& Smithies O (1996): Elevated blood pressures in mice lacking endothelial nitric oxide synthase. Proc Natl Acad Sci U S A 93: 13176-13181

23. Son H, Hawkins RD, Martin K, Kiebler M, Huang PL, Fishman MC \& Kandel ER (1996): Long-term potentiation is reduced in mice that are doubly mutant in endothelial and neuronal nitric oxide synthase. Cell 87: $1015-1023$

24. Tranguch S \& Huet-Hudson Y (2003): Decreased viability of nitric oxide synthase double knockout mice. Mol Reprod Dev 65: 175-179

25. Wei XQ, Charles IG, Smith A, Ure J, Feng GJ, Huang FP, Xu D, Muller W, Moncada S \& Liew FY (1995): Altered immune responses in mice lacking inducible nitric oxide synthase. Nature 375: 408-411

26. Brunner F, Andrew P, Wolkart G, Zechner R \& Mayer B (2001): Myocardial contractile function and heart rate in mice with myocyte-specific overexpression of endothelial nitric oxide synthase. Circulation 104: 3097-3102

27. Burkard N, Rokita AG, Kaufmann SG et al (2007): Conditional neuronal nitric oxide synthase overexpression impairs myocardial contractility. Circ Res 100: e32-e44

28. Heger J, Godecke A, Flogel U, Merx MW, Molojavyi A, Kuhn-Velten WN \& Schrader J (2002): Cardiacspecific overexpression of inducible nitric oxide synthase does not result in severe cardiac dysfunction. Circ Res 90: 93-99

29. Janssens S, Pokreisz P, Schoonjans L et al (2004): Cardiomyocyte-specific overexpression of nitric oxide synthase 3 improves left ventricular performance and reduces compensatory hypertrophy after myocardial 
infarction. Circ Res 94: 1256-1262

30. Loyer X, Gomez AM, Milliez P et al (2008): Cardiomyocyte overexpression of neuronal nitric oxide synthase delays transition toward heart failure in response to pressure overload by preserving calcium cycling. Circulation 117: 3187-3198

31. Mungrue IN, Gros R, You X, Pirani A, Azad A, Csont T, Schulz R, Butany J, Stewart DJ \& Husain M (2002): Cardiomyocyte overexpression of iNOS in mice results in peroxynitrite generation, heart block, and sudden death. J Clin Invest 109: 735-743

32. Ohashi Y, Kawashima S, Hirata K, Yamashita T, Ishida T, Inoue N, Sakoda T, Kurihara H, Yazaki Y \& Yokoyama M (1998): Hypotension and reduced nitric oxide-elicited vasorelaxation in transgenic mice overexpressing endothelial nitric oxide synthase. J Clin Invest 102: 2061-2071

33. Packer MA, Hemish J, Mignone JL, John S, Pugach I \& Enikolopov G (2005): Transgenic mice overexpressing nNOS in the adult nervous system. Cell Mol Biol (Noisy-le-grand) 51: 269-277

34. Takamura T, Kato I, Kimura N, Nakazawa T, Yonekura H, Takasawa S \& Okamoto H (1998): Transgenic mice overexpressing type 2 nitric-oxide synthase in pancreatic beta cells develop insulin-dependent diabetes without insulitis. J Biol Chem 273: 2493-2496

35. Van Haperen R, de Waard M, van Deel E, Mees B, Kutryk M, van Aken T, Hamming J, Grosveld F, Duncker DJ \& de Crom R (2002): Reduction of blood pressure, plasma cholesterol, and atherosclerosis by elevated endothelial nitric oxide. J Biol Chem 277: 48803-48807

36. Jones SP, Greer JJ, van Haperen R, Duncker DJ, de Crom R \& Lefer DJ (2003): Endothelial nitric oxide synthase overexpression attenuates congestive heart failure in mice. Proc Natl Acad Sci U S A 100: 48914896

37. Scherrer-Crosbie M, Ullrich R, Bloch KD et al (2001): Endothelial nitric oxide synthase limits left ventricular remodeling after myocardial infarction in mice. Circulation 104: 1286-1291

38. Ichinose F, Bloch KD, Wu JC, Hataishi R, Aretz HT, Picard MH \& Scherrer-Crosbie M (2004): Pressure overload-induced LV hypertrophy and dysfunction in mice are exacerbated by congenital NOS3 deficiency. Am J Physiol Heart Circ Physiol 286: H1070-H1075
39. Landmesser U, Engberding N, Bahlmann $\mathrm{FH}$ et al (2004): Statin-induced improvement of endothelial progenitor cell mobilization, myocardial neovascularization, left ventricular function, and survival after experimental myocardial infarction requires endothelial nitric oxide synthase. Circulation 110: 1933-1939

40. Liu YH, Xu J, Yang XP, Yang F, Shesely E \& Carretero OA (2002): Effect of ACE inhibitors and angiotensin II type 1 receptor antagonists on endothelial NO synthase knockout mice with heart failure. Hypertension 39: 375-381

41. Hafezi-Moghadam A, Simoncini T, Yang Z et al (2002): Acute cardiovascular protective effects of corticosteroids are mediated by non-transcriptional activation of endothelial nitric oxide synthase. Nat Med 8: 473-479

42. Massion PB \& Balligand JL (2003): Modulation of cardiac contraction, relaxation and rate by the endothelial nitric oxide synthase (eNOS): lessons from genetically modified mice. J Physiol 546: 63-75

43. Prabhu SD (2004): Nitric oxide protects against pathological ventricular remodeling: reconsideration of the role of NO in the failing heart. Circ Res 94: $1155-1157$

44. Dawson D, Lygate CA, Zhang $\mathrm{MH}$, Hulbert $\mathrm{K}$, Neubauer S \& Casadei B (2005): nNOS gene deletion exacerbates pathological left ventricular remodeling and functional deterioration after myocardial infarction. Circulation 112: 3729-3737

45. Saraiva RM, Minhas KM, Raju SV, Barouch LA, Pitz E, Schuleri KH, Vandegaer K, Li D \& Hare JM (2005): Deficiency of neuronal nitric oxide synthase increases mortality and cardiac remodeling after myocardial infarction: role of nitroso-redox equilibrium. Circulation 112: $3415-3422$

46. Casadei B (2006): The emerging role of neuronal nitric oxide synthase in the regulation of myocardial function. Exp Physiol 91: 943-955

47. Feng Q, Lu X, Jones DL, Shen J \& Arnold JM (2001): Increased inducible nitric oxide synthase expression contributes to myocardial dysfunction and higher mortality after myocardial infarction in mice. Circulation 104: 700-704

48. Liu YH, Carretero OA, Cingolani OH, Liao TD, Sun Y, Xu J, Li LY, Pagano PJ, Yang JJ \& Yang XP (2005): Role of inducible nitric oxide synthase in cardiac 
function and remodeling in mice with heart failure due to myocardial infarction. Am J Physiol Heart Circ Physiol 289: H2616-H2623

49. Sam F, Sawyer DB, Xie Z, Chang DL, Ngoy S, Brenner DA, Siwik DA, Singh K, Apstein CS \& Colucci WS (2001): Mice lacking inducible nitric oxide synthase have improved left ventricular contractile function and reduced apoptotic cell death late after myocardial infarction. Circ Res 89: 351-356

50. Zhang $P, X u X, H u X$, van Deel ED, Zhu G \& Chen Y (2007): Inducible nitric oxide synthase deficiency protects the heart from systolic overload-induced ventricular hypertrophy and congestive heart failure. Circ Res 100: 1089-1098

51. Mungrue IN, Husain M \& Stewart DJ (2002): The role of NOS in heart failure: lessons from murine genetic models. Heart Fail Rev 7: 407-422

52. Saraiva RM \& Hare JM (2006): Nitric oxide signaling in the cardiovascular system: implications for heart failure. Curr Opin Cardiol 21: 221-228

53. Suda O, Tsutsui M, Morishita T, Tanimoto A, Horiuchi M, Tasaki H, Huang PL, Sasaguri Y, Yanagihara N \& Nakashima Y (2002): Long-term treatment with $\mathrm{N}$ (omega)-nitro-L-arginine methyl ester causes arteriosclerotic coronary lesions in endothelial nitric oxide synthase-deficient mice. Circulation 106: 17291735

54. Suda O, Tsutsui M, Morishita T et al (2004): Asymmetric dimethylarginine produces vascular lesions in endothelial nitric oxide synthase-deficient mice. Arterioscler Thromb Vasc Biol 24: 1682-1688

55. Tsutsui M, Shimokawa H, Morishita T, Nakashima Y \& Yanagihara N (2006): Development of genetically engineered mice lacking all three nitric oxide synthases. J Pharmacol Sci 102: 147-154

56. Nakata S, Tsutsui M, Shimokawa H et al (2008): Spontaneous myocardial infarction in mice lacking all nitric oxide synthase isoforms. Circulation 117: 22112223

57. Tsutsui M, Nakata S, Shimokawa H, Otsuji Y \& Yanagihara N (2008): Spontaneous myocardial infarction and nitric oxide synthase. Trends Cardiovasc Med 18: 275-279
58. Shibata K, Yatera Y, Furuno Y et al (2010): Spontaneous development of left ventricular hypertrophy and diastolic dysfunction in mice lacking all nitric oxide synthases. Circ J 74: 2681-2692

59. Ho KK, Pinsky JL, Kannel WB \& Levy D (1993): The epidemiology of heart failure: the Framingham Study. J Am Coll Cardiol 22: 6A-13A

60. Yamamoto K, Sakata Y, Ohtani T, Takeda Y \& Mano T (2009): Heart failure with preserved ejection fraction. Circ J 73: 404-410

61. Zile MR \& Brutsaert DL (2002): New concepts in diastolic dysfunction and diastolic heart failure: Part I: diagnosis, prognosis, and measurements of diastolic function. Circulation 105: 1387-1393

62. Buys ES, Sips P, Vermeersch P, Raher MJ, Rogge E, Ichinose F, Dewerchin M, Bloch KD, Janssens S \& Brouckaert P (2008): Gender-specific hypertension and responsiveness to nitric oxide in sGCalphal knockout mice. Cardiovasc Res 79: 179-186

63. Du XJ, Samuel CS, Gao XM, Zhao L, Parry LJ \& Tregear GW (2003): Increased myocardial collagen and ventricular diastolic dysfunction in relaxin deficient mice: a gender-specific phenotype. Cardiovasc Res 57: 395-404

64. Silberman GA, Fan TH, Liu H et al (2010): Uncoupled cardiac nitric oxide synthase mediates diastolic dysfunction. Circulation 121: 519-528

65. Abraham TP, Jones M, Kazmierczak K, Liang HY, Pinheiro AC, Wagg CS, Lopaschuk GD \& SzczesnaCordary D (2009): Diastolic dysfunction in familial hypertrophic cardiomyopathy transgenic model mice. Cardiovasc Res 82: 84-92

66. Calderone A, Thaik CM, Takahashi N, Chang DL \& Colucci WS (1998): Nitric oxide, atrial natriuretic peptide, and cyclic GMP inhibit the growth-promoting effects of norepinephrine in cardiac myocytes and fibroblasts. J Clin Invest 101: 812-818

67. Paulus WJ, Vantrimpont PJ \& Shah AM (1994): Acute effects of nitric oxide on left ventricular relaxation and diastolic distensibility in humans. Assessment by bicoronary sodium nitroprusside infusion. Circulation 89: $2070-2078$ 
一酸化窒素合成酵素と心不全 一 遺伝子改変マウスからの教訓

柴田 清子 ${ }^{1}$, 下川 宏明 ${ }^{2}$, 柳原 延章 ${ }^{3}$, 尾辻 豊 ${ }^{1}$, 筒井 正人 ${ }^{4}$

1 産業医科大学 医学部 第 2 内科学

2 東北大学大学院 医学系研究科 循環器内科学

3 産業医科大学 医学部 薬理学

${ }^{4}$ 琉球大学大学院 医学研究科 薬理学

要旨：一酸化窒素 $(\mathrm{NO})$ 合成酵素 $(\mathrm{NOS})$ には, 神経型, 誘導型, 内皮型の 3 種類の NOS アイソフォームが存在す る。ヒト心臓には, すべての NOSsが発現している。従来,心不全におけるNOSsの役割が, NOS 阻害薬を用いて研究 されてきた。さらに,近年では, 遺伝子改変動物が実験に使用されるようになり, ヒト心不全におけるNOSsの役割 の理解に重要な示唆を与えている。我々は, NOSアイソフォームを欠損させたNOS遺伝子改変マウスを用いて, そ の心臟の構造と心機能を評価した。 その結果, 3 種類の NOSアイソフォームを欠損させた triple NOS 欠損マウスにだ け, 有意な求心性肥大と拡張障害があり, その病態は, ヒトの拡張期心不全に酷似していることを明らかにした。ま た, AT1受容体拮抗薬を負荷した結果, それらの病態が抑制されたことから,これらの機序には, AT1受容体を介して いることが示唆された. triple NOS 欠損マウスを用いた研究は, ヒト心不全に㧍けるNOSsの役割の解明に, 大きく 寄与したものと言える.

キーワード : 一酸化窒素合成酵素, 心不全, 左室肥大, マウス.

J UOEH(産業医大誌) 35(2)：147 - 158(2013) 